\title{
Research on Accounting Information Disclosure in Colleges and Universities
}

\author{
Xiangling Yu \\ Shandong Jiaotong University, Weihai, Shandong, China
}

\begin{abstract}
Keywords: Disclosure of accounting information; Universities directly under the Ministry of Education; Accounting information in colleges and universities; Deviation of budget and final accounts
\end{abstract}

\begin{abstract}
The improvement of information technology means has continuously promoted the improvement of the degree of information disclosure, and the continuous disclosure of information has stimulated the new information demand. The demand for the disclosure of accounting information is growing day by day, especially since China has continuously increased its investment in education, the public's demand for the disclosure of this issue is even more urgent. This paper uses the accounting information that has already been disclosed in colleges and universities to analyze its present disclosure situation and uses index method to evaluate the quality of accounting information disclosure. With the method of empirical analysis, it is found that the main factors affecting the disclosure of accounting information in colleges and universities are the income of colleges and universities, the implementation of budget and final accounts, and the demand for disclosure of accounting information. Based on the above factors, some suggestions are put forward to strengthen the disclosure of accounting information in colleges and universities.
\end{abstract}

\section{Introduction}

The " Measures for Information Disclosure in Institutions of Higher Learning" formulated by the Ministry of Education provides a policy basis for the standardization of information disclosure in institutions of higher learning. With the implementation of the Measures, the work of information disclosure in our country has extended from the government level to public enterprises and institutions, stipulating the requirements of information disclosure in terms of content, form and procedure. As a public welfare institution, information disclosure in colleges and universities has received wide attention, and the state also attaches great importance to this event. For example, in the national medium - and long-term education reform and development plan ( 2010 - 2020 ), the measures for information disclosure of colleges and universities promulgated in 2010, and the notice of the Ministry of education on further improving the financial information disclosure of colleges and universities, all put forward requirements for information disclosure of colleges and universities. it can be seen that a consensus has been reached to strengthen the disclosure of accounting information of colleges and universities and enhance the transparency of university finance: through the disclosure of financial information of colleges and universities, stakeholders can monitor the financial situation, work efficiency and efficiency, and budget implementation of colleges and universities.

Since 2012, colleges and universities have started to disclose their budget and final accounts information, especially the final accounts information in 2013 and the budget information in 2014, and colleges and universities directly under the Ministry of Education have basically done so. Although initial progress has been made in information disclosure with " school affairs publicity" as the main method, on the whole there are still some shortcomings in information disclosure in colleges and universities, such as procedures, institutionalization, low standardization and weak implementation. 


\section{Related concept definition and theoretical basis}

The accounting information of colleges and universities refers to the information about the accounting process embodied in financial management. In addition to the information on income, expenditure and balance referred to in accounting information in the usual sense, there are also information on income budget, income final accounts, expenditure budget and expenditure final accounts disclosed by colleges and universities in accordance with regulations, as well as asset management, loan information, liability information and donations from the public to colleges and universities.

\subsection{Information disclosure in colleges and universities}

In terms of the content of information disclosure in colleges and universities, the Measures specify the scope and items that need to be voluntarily disclosed according to regulations, including 12 types of information including basic information about schools and financial asset management, and should compile and update information disclosure catalogues and guidelines in a timely manner. In addition to the information voluntarily disclosed by colleges and universities, colleges and universities should also accept the public's application for information disclosure due to information needs, so as to meet the legitimate applications of all sectors of society.

In the way of information disclosure in colleges and universities, the Measures also made detailed requirements. Colleges and universities need to carry out various ways to disclose information according to their own operating conditions. The public channels mentioned in the Measures mainly include: (1) the campus media, including websites of colleges and universities, school newspapers and periodicals, campus broadcasting, etc.; (2) off-campus media, including newspapers, magazines, radio and television; (3) Written forms, such as yearbooks, minutes of meetings or briefings; (4) other open channels, press conferences, public consultation rooms set up on demand, information collection points, information bulletin boards or electronic screens, etc.

\subsection{Deviation Degree of University Budget and Final Accounts}

Due to the lack of research on the deviation degree of government budget and final accounts, the concept of deviation degree of university budget and final accounts is a relatively new concept, and academic circles have not reached a unified understanding and definition of this concept. However, according to the definition of the deviation of government budget and final accounts in the previous article, it can be similarly concluded that the deviation of university budget and final accounts reflects the deviation between university budget and final accounts in terms of income and expenditure.

The Theoretical Basis of Accounting Information Disclosure in Colleges and Universities in China

The disclosure of accounting information in colleges and universities is also intrinsically linked to entrusted agency. As we all know, our country implements the system of people's democratic dictatorship. The people are the masters of the country and enjoy all kinds of rights and obligations. In order to practice democratic centralism, the people entrusted power to the National People's Congress, which then delegated it to the lower levels through the State Council, resulting in multiple principal-agent relationships. As far as the disclosure of accounting information in colleges and universities is concerned, the supply side of information is colleges and universities, and the demand side is various organizations, stakeholders, creditors, investors and so on, including the people. In the principal-agent relationship, colleges and universities are the end of agents. Colleges and universities accept government funding and allocate and use education funds reasonably to achieve the goal of training students. As a client, the people of course have the right to know about the public information entrusted by them. As a public institution with the nature of public welfare, the accounting information of colleges and universities naturally belongs to public information and should be voluntarily disclosed. 


\section{The Status Quo and Quality Analysis of Accounting Information Disclosure in Colleges and Universities}

In order to analyze the current situation of accounting information disclosure in colleges and universities, we first need to understand the relevant policies and regulations of our country, and then describe the current implementation situation of accounting information disclosure in colleges and universities according to the requirements of the policies and regulations.

As the relevant norms of information disclosure in colleges and universities become more detailed and perfect, it means that the institutionalization and legalization of information disclosure in colleges and universities are becoming more and more complete. With the continuous improvement of the government information disclosure work in our country, the accounting information disclosure work in public institutions has also been well developed, and the accounting information disclosure work in colleges and universities has gradually developed in a direction that can be followed by law. At present, China's regulations on the disclosure of accounting information in colleges and universities are mainly reflected in three levels: legal level, accounting standard level and other relevant regulations.

\subsection{Status of implementation}

- The individual difference of accounting information disclosure in colleges and universities is large

- The general situation of accounting information disclosure in colleges and universities basically conforms to the regulations

- Other accounting information disclosure in colleges and universities is relatively low

\subsection{The Quality of Accounting Information Disclosure in Colleges and Universities}

The index system of "China's corporate governance index" selects 6 first-class indicators, 19 second-class indicators and 80 third-class indicators to evaluate the information disclosure of listed companies. Using the evaluation methods of listed companies for reference, this paper similarly uses the "index method" to analyze the quality of accounting information disclosure in sample colleges and universities, so as to evaluate the compliance and disclosure quality of accounting information disclosure in sample colleges and universities. In the actual process of scoring, due to the different categories of each scoring item, it is necessary to formulate a targeted scoring standard.

\section{Analysis of Factors Influencing Accounting Information Disclosure in Colleges and Universities}

Colleges and universities are institutions with the nature of public welfare services. When they disclose accounting information, the information demanders include many stakeholders such as the government, the public, students, creditors and donors, so they are affected by many factors. On the whole, the factors that affect the disclosure of accounting information in colleges and universities are mainly divided into external factors and internal factors. Combined with the accounting information that has been disclosed in colleges and universities at present, this paper mainly analyzes its influencing factors from the aspects of the income of colleges and universities, the effect of budget implementation and the information needs of colleges and universities:

\subsection{Income of Colleges and Universities}

By analyzing the sources of income of colleges and universities, we can define the main principals. The income of colleges and universities mainly consists of financial allocation income, business income, operating income, income turned over by affiliated units, and other income.

According to the data published by colleges and universities directly under the Ministry of Education on their respective information disclosure websites, all the information in the final accounts of colleges and universities in 2017 is taken as the original data, and a line chart is made by dividing all the income data by the total income of the current year as shown in Figure 1. 


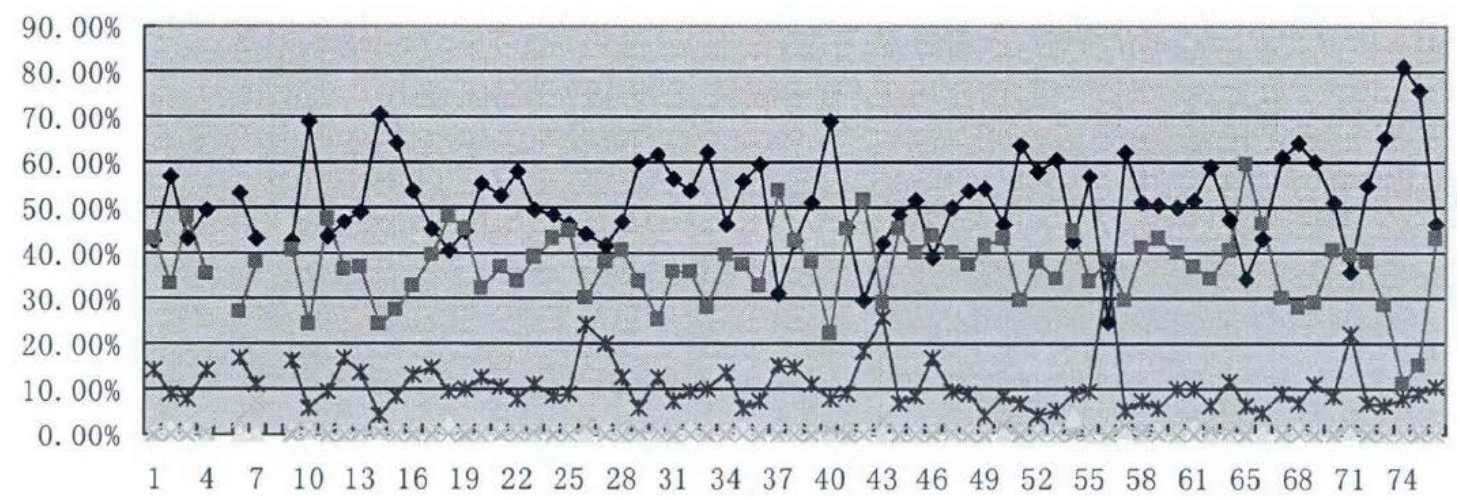

Fig. 1 Statistics and line charts of various income ratios in colleges and universities directly under the Ministry of Education

\subsection{The Budget Implementation Effect of Colleges and Universities}

According to the theory of public goods, accounting information disclosure in colleges and universities, as a quasi-public product service, should not only accept supervision from outside forces, but also face management pressure from inside the school. From the analysis of the current situation of accounting information disclosure policy in colleges and universities, it can be concluded that the ultimate goal of functional departments and regulatory departments in urging colleges and universities to make information disclosure is to supervise the results of budget implementation in colleges and universities. When submitting a copy of the results of budget execution to all ministries and departments, if the budget execution effect is good, colleges and universities may be more proactive in completing the task of accounting information disclosure, that is, the budget execution effect will affect the degree of accounting information disclosure in colleges and universities. The income deviation and expenditure deviation of colleges and universities directly under the Ministry of Education in 2016 are compiled into a line chart 2.

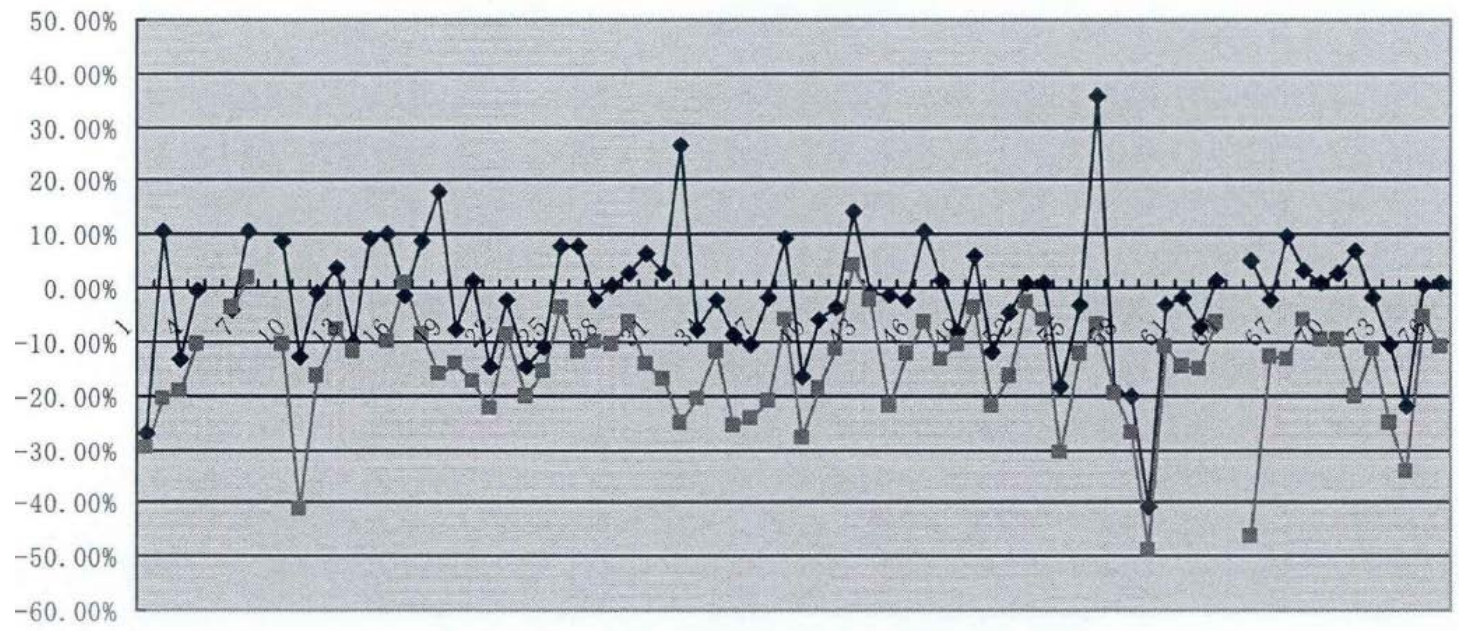

Fig. 2 Line chart of revenue and expenditure deviation

\subsection{Information Demand of Co - education}

Generally speaking, the historical evolution, academic atmosphere, social status, development prospects and comprehensive strength of colleges and universities all determine the number of their stakeholders and also reflect the size of information demand. All these aspects can be summarized as the development scale of colleges and universities. The better the development scale of colleges and universities, the more stakeholders involved and the more information needs they will involve, which will promote colleges and universities to continuously improve and develop their accounting information disclosure work. Therefore, the demand for accounting information in colleges and universities has a certain impact on the quality of accounting information disclosure. 


\section{Suggestions on Accounting Information Disclosure in Colleges and Universities}

\subsection{Strengthen the External Supervision of Accounting Information Disclosure}

According to the principal-agent theory, the different income structure of colleges and universities represents the supervision from different external forces, and the size of the income means the strength of the external supervision forces. Therefore, the stronger the external supervision power, the higher the quality of accounting information disclosure.

\subsection{Pay attention to the internal control of colleges and universities}

The budget execution of colleges and universities is a result reflecting the effect of their internal control. The better the budget execution of colleges and universities is, the higher the quality of the accounting information they disclose. Therefore, attaching importance to the internal control of colleges and universities will promote the development of accounting information disclosure in colleges and universities. It can be considered from the following aspects: constructing an internal control evaluation system

$\checkmark$ Reasonable and Standardized Budget Control

- The Role of Strengthening Internal Auditing in Colleges and Universities

\subsection{Improve the Demand for Accounting Information Disclosure}

According to the empirical test results, the accounting information needs of colleges and universities promote the degree of information disclosure. The higher the accounting information needs, the higher the quality of accounting information disclosed by colleges and universities. Therefore, in order to strengthen the disclosure of accounting information in colleges and universities, the demand for disclosure of accounting information in colleges and universities should be raised. Mainly from the following aspects:

- Strengthen the public's awareness of information needs

Improve the technical means of accounting information disclosure

\section{References}

[1] Gibson, Barbier Y. Millennial Alumni Giving: Factors for Donating to Colleges and Universities [J]. Dissertations \& Theses-Gradworks, 2015.

[2] Aleks and er Arist:ovnik. Relative Efficiency of Public Education in the New EU Member States; The Case of Primary Education [M]. Relative Efficiency of Public Education in the New EU Member States: The Case of Primary Education. ToKnowPress, 2013:237-243.

[3] Chaney P K, Faccio M,Parsley D. The quality of accounting information in politically connected firms [J]. Ssm Electronic Journal, 2011, 51(l-2):58-76.

[4] Kench B T, Wallace H S. Mapping 2007-08 TTuition and Fees In liigher Education. Journal of Applied Business Research, 2010:13-15.

[5] Zhu Zhen, Sun Yingying, Zhang Lin. Characteristics and Optimization of Capital Structure in Universities - Taking Universities Directly under the Ministry of Education as an Example. Finance and Finance, 2015 (2): 35 - 40. 